\title{
Cross reactivity between Trypanosoma cruzi and Leishmania antigens in the lymphocyte blastogenesis assay
}

\author{
Edgar Marcelino Carvalho ${ }^{1}$, Steven G. Reed ${ }^{2}$ and Warren D. Johnson, Jr \\ ${ }^{I}$ Federal University of Bahia, Salvador, Brazil; ${ }^{2}$ Cornell University Medical College, New York, USA
}

\begin{abstract}
The in vitro blastogenesis response of lymphocytes from 19 patients, with either visceral or mucocutaneous leishmaniasis or Chagas disease, to antigens of the Leishmania-Trypanosoma complex was studied. Cells from all patients responded to both homologous and heterologous antigens and the magnitude of the responses did not differ for any of the patient groups or antigens.
\end{abstract}

\section{Introduction}

Chagas disease and visceral and cutaneous leishmaniasis are caused by intracellular protozoa of the Leishmania-Trypanosoma complex. Biological and biochemical similarities have been documented among these parasites (DWYER, 1977; MOLYNEUX \& ASHFORD, 1983). Cross-reactivity occurs with the complement fixation test, immunofluorescence antibody test, and direct agglutination reaction (CAMARGo et al., 1973; CAMARGO \& REBONATO, 1969; FIFE \& KENT, 1960); some distinction is possible between these diseases using the enzyme-linked immunosorbent assay (ELISA) (GUIMARES et al., 1981).

Chagas disease and both forms of leishmaniasis are endemic in the state of Bahia, Brazil (CuBA CuBA et al., 1980; MOTT et al., 1976; SHERLOCK, 1965; TEIXEIRA et al., 1978b). The present study examines whether a lymphocyte blastogenesis assay employing $T$. cruzi, $L$. mexicana amazonensis, and $L$. donovani chagasi antigens exhibits specificity which would distinguish between these diseases.

\section{Materials and Methods}

The subjects included 7 active cutaneous leishmaniasis (ACL) patients, 6 subjects with treated American visceral leishmaniasis (AVL), 6 chronic Chagas disease patients, and 6 healthy volunteers. The patients resided in areas of the state of Bahia which wcre recognized as having only one of these three diseases. The diagnosis of cutaneous leishmaniasis was based on clinical examination, positive Leishmania skin test, and positive Leishmania serology. The age of the ACL patients ranged from 6 to 48 years with a mean of $27 \pm 15$ years. 2 patients had only cutaneous lesions and 5 had nasal mucosal lesions. 5 of the 7 had not received specific therapy at the time of the study; 2 patients had received 2 courses of pentavalent antimonials in the past but the disease had recurred. The 6 treated AVL patients had the diagnosis of leishmaniasis established by the isolation of $L$. donovani chagasi from bone marrow aspirates. They were treated with one or more courses of pentavalent antimony 3 to 8 years (mean 5.1 years) before being studied. The treated AVL group had an age range from 4 to 18 years with a mean of $11 \pm 5 \cdot 1$ years. The diagnosis of chronic Chagas disease was established in 6 patients by clinical and serologic evaluation. The mean age of the Chagas patients was $30 \pm 10$ years, with ages ranging from 19 to 49 years. 5 of the 6 patients had heart disease characterized by arrhythmias; heart failure was present in 3 patients. The only patient that did not have heart involvement had a megacolon documented by $x$-ray. 6 healthy medical students and hospital employees served as controls.

This work was supported by a grant from the U.S. Public Health Service (Al 16282).
A strain of L. mexicana amazonensis (MHOM/BR/76/ Josepha), which was isolated from a patient with cutaneous leishmaniasis in the state of Goias, was used as an antigen source. The strain was initially cultured in NNN medium and subsequently maintained in 199 medium supplemented with foetal calf serum. The strain was characterized by isoenzymes, kinetoplast DNA, and monoclonal antibodies. A strain of $L, d$. chagasi ( $M H O M / B R / 82 / B A-3$ ), isolated from the bone marrow of a patient in the state of Bahia, was another source of antigen (CARVALHO et al., 1981). T. cruzi (Tulahuen strain) antigen was prepared from epimastigotes cultured in the dialysate medium of NAKAMURA (1967). Antigens were prepared in the following manner. Leishmania promastigotes and $T$. cruzi epimastigotes were washed three times in phosphate buffered saline (PBS), resuspended in $\mathrm{PBS}$, and rapidly frozen $\left(-70^{\circ} \mathrm{C}\right)$ and thawed $\left(37^{\circ} \mathrm{C}\right)$ six times. The lysate was sonicated and centrifuged $(14000 \mathrm{~g})$ for 30 minutes. The supernatant was collected and the protein concentration was determined by the method of LowRY $e t$ al. (1951). The antigen preparations were stored at $-20^{\circ} \mathrm{C}$ and used in concentrations ranging from 0.5 to $25 \mu \mathrm{g}$ of protein per $\mathrm{ml}$ of cell culture medium.

Human peripheral blood mononuclear cells were separated from heparinated venous blood by density gradient centrifugation using lymphocyte separation medium (Bionetics Products Laboratories, Kensington, MD) as previously described (WHO/IARC Workshop, 1974). The mononuclear cell band was washed twice in RPMI (Gibco Laboratories, Grand Island, New York, USA) and incubated at $37^{\circ} \mathrm{C}$ for 1 hour. The cells were washed and resuspended in RPMI supplemented with $15 \%$ heated $\left(56^{\circ} \mathrm{C}\right.$ for $30 \mathrm{~min}$ ) pooled human $\mathrm{AB}+$ serum at a final concentration of $10^{6}$ cells per $\mathrm{ml}$. Aliquots $(0.2 \mathrm{ml})$ of this cell suspension were cultured in triplicate in flat bottomed microtitre plates (Linbro Chemical Co., New Haven, Connecticut, USA) with $L$. mexicana, $L$. donovani chagasi, and $T$. cruzi antigens in concentrations ranging from 0.5 to $2.5 \mu \mathrm{g} / \mathrm{ml}$ of culture media. The ccll cultures were incubated for five days at $37^{\circ} \mathrm{C}$ in $5 \% \mathrm{CO}_{2}$ $95 \%$ air. After a $41 / 2 \mathrm{~h}$ pulse of cell cultures with $1 \mu \mathrm{Ci}$ of ${ }^{3} \mathrm{H}$-thymidine $(6.7 \mathrm{Ci} / \mathrm{mM})$ (New England Nuclear Corp., Boston, Massachusetts, USA) the cells were harvested and ${ }^{3} \mathrm{H}$-thymidine incorporation measured.

\section{Results}

The lymphocyte reactivity of the leishmaniasis and Chagas disease patients to the Leishmania and $T$. cruai antigens is shown in Table 1. All 19 patients responded to the homologous antigen at one or more of the concentrations employed $(0.5,5,25 \mu \mathrm{g}$ of protein $/ \mathrm{ml}$ ). The criterion for response was a 5 -fold or

Please address all correspondence and reprint requests to: Edgar M. Carvalho, Dept. of Medicine, Federal University of Bahia, Hospital Prof. Edgard Santos, 40.000 Salvador, Bahia, Brazil. 
Table 1-Lymphocyte reactivity of leishmaniasis and Chagas disease patients to Leishmania and $T$. cruzi antigens

Final

concentration and species of antigen protein

$0.5 \mu \mathrm{g} / \mathrm{ml}$

L. d. chagasi

L. mexicana

T. cruzi

$5 \mu \mathrm{g} / \mathrm{ml}$

L. d. chagasi

T. cruzi

$25 \mu \mathrm{g} / \mathrm{ml}$

L. d. chagasi

L. mexicana

T. crusi

Mean ${ }^{3} \mathrm{H}$ thymidine uptake $\left(\mathrm{cpm} \times 10^{-3}\right)$ of study groups ${ }^{\star}$

\begin{tabular}{|c|c|c|}
\hline $\begin{array}{c}\text { Visceral } \\
\text { leishmaniasis } \\
n=6\end{array}$ & $\begin{array}{c}\text { Cutaneous \& mucosal } \\
\text { leishmaniasis } \\
n=7\end{array}$ & $\begin{array}{l}\text { Chagas disease } \\
n=6\end{array}$ \\
\hline $\begin{array}{l}13 \pm 6.9 \star \star \\
3 \pm 0.9 \\
1 \pm 0.8^{\star \star}\end{array}$ & $\begin{array}{l}4 \pm 1 \cdot 7 \\
8 \pm 2 \cdot 7 \\
2 \pm 0 \cdot 4\end{array}$ & $\begin{array}{l}2 \pm 0.9 \\
4 \pm \quad 2.3 \\
8 \pm 1.6\end{array}$ \\
\hline $\begin{array}{r}17 \pm 7 \cdot 0 \\
8 \pm 1 \cdot 6 \\
9 \pm 4 \cdot 6\end{array}$ & $\begin{array}{l}14 \pm 5 \cdot 8 \\
25 \pm 5 \cdot 3 \\
12 \pm 4 \cdot 4\end{array}$ & $\begin{array}{r}6 \pm 2 \cdot 1 \\
15 \pm 6 \cdot 3 \\
14 \pm 3 \cdot 3\end{array}$ \\
\hline $\begin{array}{l}17 \pm 5 \cdot 7 \\
18 \pm 4 \cdot 1 \\
12 \pm 3 \cdot 9\end{array}$ & $\begin{array}{l}23 \pm 9 \cdot 7 \\
33 \pm 7 \cdot 5 \\
19 \pm 4 \cdot 3\end{array}$ & $\begin{array}{r}8 \pm 4 \cdot 8 \\
19 \pm 9 \cdot 1 \\
29 \pm 12 \cdot 1\end{array}$ \\
\hline
\end{tabular}

* The mean and standard deviation of the unstimulated cultures were as follows: $0.5 \pm 0.1$ for cutaneous leishmaniasis patients; $0.4 \pm 0.1$ for treated visceral leishmaniasis patients; and $1.3 \pm 0.4$ for Chagas disease patients.

$\star p^{\circ}<0.05$; statistical analysis was performed by the rank sum test.

greater increase in thymidine incorporation as compared to unstimulated cells. All patients also responded to at least one heterologous antigen and 15 of the 19 patients responded to both heterologous antigens. The 4 non-responders included an AVL patient with $T$. cruzi antigen, a Chagas disease patient with $L$. d. chagasi antigen, and 2 cutaneous leishmaniasis patients, one with $T$. cruzi antigen and another with $L$. d. chagasi antigen. In general, the mean response of the 3 groups of patients to both homologous and heterologous antigens was increased at the higher antigen concentrations. However, these differences were not significant for any of the patient groups or antigens $(P>0.05)$. The only significant difference observed was the difference in the mean response of the six AVL patients to $L$. $d$. chagasi and $T$. cruzi antigens at a concentration of $0.5 \mu \mathrm{g}$ of protein $/ \mathrm{ml}$.

\section{Discussion}

These results indicate that patients with leishmaniasis and Chagas disease respond to both homologous and heterologous antigens in an in vitro lymphocyte blastogenesis assay. Although the response to the homologous antigen was generally greater than the responses to heterologous antigens, the only significant difference was that of the visceral leishmaniasis patients to $L$. $d$. chagasi and $T$. cruzi antigens. This latter finding is consistent with a specificity we have observed in the delayed-type hypersensitivity skin test in AVL and Chagas disease patients employing the same $L$. $d$. chagasi antigen as was used in the blastogenesis assay (R. Badaro et al., personal communication). In these studies, positive skin tests were obtained with $25 \mu \mathrm{g}$ of $L$. d. chagasi protein in 37 of 40 subjects with cured visceral leishmaniasis and in none of 30 patients with chronic Chagas disease.

The cross reactivity observed in the blastogenesis assay indicates that it is not of diagnostic value in patients with leishmaniasis and Chagas disease. It does raise complex questions as to how concomitant infection with $T$. cruzi and Leishmania might influence each other. Present knowledge of host defence and pathogenesis of these diseases (CARVALHO et al., 1981; MURRAY et al., 1982; NogUEIRA et al., 1982; SADIGURSKY et al., 1982; TEIXEIRA et al., 1978) could be interpreted to suggest that coexistent infections might potentiate each other or, alternatively, that prior infection with a related protozoon might have some protective value against other organisms.

\section{References}

Camargo, M. EE., \& Rebonato, C. (1969). Cross reactivity in fluorescence tests for Trypanosoma and Leishmania antibodies. A simple inhibition procedure to ensure specific results. American foumal of Tropical Medicine and Hygiene, 18, 500-505.

Camargo, M. E., Hoshino-Shimizu, S. \& Siqueira, G. R. (1973). Hemagglutination with preserved sensitized cells. A practical test for routine serologic diagnosis of American trypanosomiasis. Revista do Instituto de Medicina Tropical de Sâo Paulo, 15, 81-85.

Carvalho, E. M., Teixeira, R. \& Johnson, W. D. (1981). Cell-mediated immunity in American visceral leishmaniasis: reversible immunosuppression during acute infection. Immunity, 33, 498-502.

Cuba Cuba, C. A., Marsden, P. D., Barreto, A. C., Rocha, R., Sampaio, R. R. \& Patzlaff, L. (1980). Diagnostico parasitologico e imunologico de leishmaniasis tegumentaria americana. Boletin de la Oficina Sanitaria Panamericana, 89, 195-208.

Dwyer, D. M. (1977). Leishmania donovani: surface membrane carbohydrates of promastigotes. Experimental $\mathrm{Pa}$ rasitology, 41, 341-358.

Fife, E. H., Jr \& Kent, J. F. (1960). Protein and carbohydrate complement-fixing antigens of Trypanosoma crusi. American Foumal of Tropical Medicine and Hygiene, 9, 512.517.

Guimaraes, M. C. S., Celeste, B. J., de Castilho, E. A., Mimeo, J. R. \& Diniz, J. M. P. (1981). Immunoenzymatic assay (ELISA) in mucocutaneous leishmaniasis, kala-azar and Chagas' disease: an epimastigote Trypanosoma cruzi antigen able to distinguish between antitrypanosoma and anti-leishmania antibodies. American Fournal of Tropical Medicine and Hygiene, 30, 942-947.

Lowry, O. H., Rosebrough, N. G., Farr, A. L. \& Randall, R. J. (1951). Protein measurement with the Folin phenol reagent. Foumal of Biological Chemistry, 193, 265-275.

Molyneux, D. H. \& Ashford, R. W. (1983). The biology of Trypanosoma and Leishmania: parasites of man and 
domestic animals. New York: International Publications Service; Taylor \& Francis, Inc.

Mott, K. E., Lehman, J. S., Hoff, R., Morrow, R., Muniz, T. M., Sherlock, I., Draper, C. C., Pugliese, C. \& Guimaraes, A. C. (1976). The epidemiology and household distribution of seroreactivity to Trypanosoma cruzi in a rural community in northeast Brazil. American foumal of Tropical Medicine and Hygiene, 25, 552-562.

Murray, H. W., Masur, H. \& Keithly, J. S. (1982). Cell-mediated immune response in experimental visceral leishmaniasis I. Correlation between resistance to Leishmania donovani and lymphokine genlerating capacity. Foumal of Immunology, 129, 344-350.

Nakamura, M. (1967). Culture of Trypanosoma cruet in a protein-free dialysate medium. Proceedings of the Society for Experimental Biology and Medicine, 12, 779-780.

Nogueira, N., Chaplan, S., Reesink, M., Tydinigs, J. \& Cohn, Z. A. (1982). Trypanosoma cruzi: induction of micrubicidal activity in human mononuclear phagocytes. Foumal of Immunology, 128, 2142-2146.

Sadigursky, M., Acosta, A. \& Santos-Buch, C. A. (1982). Muscle sarcoplasmic reticulum antigen shared by a
Trypanosoma cruzi clone. American Joumal of Tropical Medicine and Hygiene, 31, 934-941.

Sherlock, I. A. (1965). Observaçao sobre Calazar em Jacobina I. Historico e dados preliminares, Revista Brasileira de Malariologia e Doenças Tropicais, 2, 532-536.

Teixeira, A. R. L., Teixeira, G., Macedo, V. \& Prata, A. (1978a). Trypanosoma cruzi-sensitized T-lymphocyte mediated ${ }^{51} \mathrm{Cr}$ release from human heart cells in Chagas' disease. American Joumal of Tropical Medicine and Hygiene, 27, 1097-1107.

Teixeira, A. R. L., Teixeira, G., Macedo, V. \& Prata, A. (1978b). Acquired cell-mediated immunodepression in acute Chagas' disease. Fournal of Clinical Investigation, 62, 1132-1141.

WHO/IARC Workshop (1974). Special technical report. Identification, enumeration and isolation of blood $T$ lymphocytes from human peripheral blood. Scandinavian fournal of Immunology, 3, 521-532.

Accepted for publication 18th November, 1985

\section{Book Review}

Trypanosomiasis Control and African Development. A. M. Jordan. London \& New York: Longman, 1986. $x+357$ pp., illus. Price: S30. ISBN: 0582 463564 .

This book starts with a useful, if brief, review of tsetse flies, the trypanosomes they transmit, and the vertebrate hosts of both. Finer points of parasite structure and taxonomy are not dealt with. Then follow a chapter each on the human and animal trypanosomiases which, again, provide useful summaries on an inevitably superficial level. The book then moves on, via an introduction to tsetse ecology, to its major concern - methods and effects of controlling trypanosomiasis, mainly by controlling its vector. Perhaps the most valuable part of the book, and the most interesting to me, is the three chapters reviewing methods of tsetse control. The effects of human settlement, and the economics of control (a subject barely studied), are discussed, and the author then considers the interactions between control and land usage - a topic largely ignored in the early, naively optimistic days of control. The penultimate chapter interestingly discusses three current controversies, introduced by three "emotive statements" - "removal of tsetse flies results in land degradation", "insecticides used for tsetse control are polluting
Africa", and "a better choice: wildlife, not cattle". To these statements, the author's responses can be summarized, respectively, as: not necessarily true, not if we are careful, and unrealistic. The final chapter considers "The future?" - and the question mark is significant. Jordan concludes that "techniques for effectively controlling trypanosmiasis are available, [but] the difficulties of applying them are immense...". He challenges the view that control should be given low priority, or even, in the late John Ford's view (1971: The role of the trypanosomes in African ecology. Clarendon Press, Oxford), deliberately not be pursued in the hope that a (perhaps mythical) erstwhile state of biological harmony will be reacquired.

In conclusion, this is not a textbook, not a reference work, but it is a book to be read with interest and enjoyment by everyone - lay person, physician or scientist - with an interest in Africa and Africans and particularly by those with a role to play in planning the future development of African nations. The book is well referenced (over 450 citations) and indexed, and well produced (I did not notice a single misprint). 